\title{
Kilis İli İçin Farklı Yüksekliklerdeki Rüzgâr Potansiyelinin Belirlenmesi
}

\author{
Furkan DINÇER $^{1 *}$, Sabir RÜSTEMLİ ${ }^{2}$, Şaban YILMAZ ${ }^{1}$, Ali ÇINGI $^{1}$ \\ ${ }^{1}$ Kilis 7 Aralı Üniversitesi, Elektrik-Elektronik Mühendisliği Bölümü, Kilis \\ ${ }^{2}$ Bitlis Eren Üniversitesi, Elektrik-Elektronik Mühendisliği Bölümü, Bitlis
}

\begin{abstract}
Özet
Günümüzde kullanılan en yaygın yenilenebilir enerji kaynaklarından bir tanesi de rüzgâr enerjisidir. Bu çalısmada Kilis ili için 10 metre yükseklikteki rüzgâr hız değerleri baz alınarak 30, 40, 60 ve 80 metre yüksekliklerindeki rüzgâr hızları hesaplanmıştır. Böylece, Kilis İli için yıllık rüzgâr enerjisi potansiyeli hesaplanmıştır. Ayrıca farklı iller için de var olan rüzgâr hızı değerlerine bağlı olarak farklı yükseklikteki rüzgâr hızları hesaplanabilmektedir. Bu sayede kurulmak istenen rüzgâr türbinin de seçimi doğru bir şekilde yapılmaktadır.
\end{abstract}

Anahtar kelimeler: Rüzgâr Potansiyeli, Rüzgâr Hesabı, Kilis.

\section{Determination of Wind Potential at Different Heights for Kilis}

\begin{abstract}
Today, one of the most common used renewable energy sources is wind energy. In this study, wind speeds of 30 , 40, 60 and 80 meters were calculated for Kilis province on the basis of $10 \mathrm{~m}$ high wind speed values. Thus, the annual wind energy potential for Kilis province is calculated. Wind speeds at different heights can also be calculated depending on the wind speed values that exist for different regions. The choice of the wind turbine to be installed on this site is also made correctly.
\end{abstract}

Keywords: Wind Potential, Wind Calculation, Kilis.

\section{Giriş}

Dünyamızda artan nüfus ve gelişen sanayiye bağlı olarak her geçen gün enerji ihtiyacı artmaktadır. Her geçen gün artan enerji talebi var olan enerji kaynaklarının yanında yeni enerji kaynaklarının da ortaya konması ile kaynakların çeşitlenmesine neden olmaktadır [1]. 1900'lü yıllarda sadece petrol, doğalgaz, kömür gibi doğada hali hazırda bulunan enerji kaynakları kullanılırken günümüzde bu kaynaklara ek olarak yenilenebilir enerji kaynakları adı altında hidrolik, biyokütle, rüzgâr, güneş, jeotermal gibi enerji kaynakları da kullanılmaktadır [2].

Yenilenebilir enerji kaynaklarının ve alternatif enerji kaynaklarının ortaya çıkmasında bir diğer etken ise kömür, petrol, doğalgaz gibi yenilenebilir olmayan enerji kaynaklarının hızlı bir şekilde tükenmesi ve bu enerji kaynaklarının çevresel etkileri de yenilenebilir enerji kaynaklarının kullanılmasında önemli bir etken oluşturmaktadır [3-4].

Bu çalışmada kullanımı her geçen gün artan yenilenebilir enerji kaynaklarının önemi vurgulanarak, yenilenebilir enerji kaynaklarından birisi olan rüzgâr enerjisi potansiyelinin ülkemizdeki durumu ve potansiyeli belirtilerek bölgeler bazında rüzgâr potansiyelleri ve hızları verilmektedir. Ayrıca Kilis ili baz alınarak farklı yüksekliklerdeki rüzgâr hızlarının belirlenmesi için var olan literatür çalışmaları incelenerek rüzgâr hızlarının tespiti için kullanılan yöntemler analiz edilerek daha önce tahmini yönteme göre rüzgâr hızının tespit edilmediği görülmektedir. Bu çalışma ile birlikte rüzgâr belirli bir yükseklikteki rüzgâr hızı baz alınarak farklı yüksekliklerdeki rüzgâr hızlarının belirlenmesi daha kolay ve pratik bir hale gelmektedir.

\footnotetext{
*Sorumlu yazar: furkandincer@kilis.edu.tr

Geliş Tarihi: 16/03/2017 Kabul Tarihi: 19/05/2017
} 


\section{Yenilenebilir Enerji Kaynaklarının Önemi ve Ülkemiz}

Birincil tüketim kaynağı olan fosil yakıtları 1998 yılına gelindiğinde enerji tüketiminin \%90'nı oluşturmaktaydı. Dünyadaki fosil yakıt rezervlerinin sınırlı olması ve hızlı bir şekilde tüketilmesi yenilenebilir enerji kaynaklarının öneminin artmasına neden olmaktadır [5]. Ayrıca kullanıma bağlı olarak ortaya çıkan $\mathrm{CO}_{2}$ ve zehirli gazlar yenilenebilir enerji kaynaklarının önemini önemli ölçüde artırmaktadır.

Yenilenebilir enerji kaynakları; "tükenme riski olmayan, kaynağının tükenme hızından daha hızlı bir şekilde kendisini yenileyen enerji kaynağı" olarak da tanımlanabilmektedir [6]. Bu enerji kaynaklarını hidrolik enerjisi, rüzgâr enerjisi, güneş enerjisi, biyokütle enerjisi ve jeotermal enerji olarak 5 ana başlık altında toplanabilmektedir. Yenilenebilir enerji kaynaklarını farklı yöntemler ile çeşitlendirmek de mümkündür. Yenilenebilir enerji kaynaklarının önemini artıran bir diğer etmen ise enerjide dışa bağımlılı̆̆ı azaltıyor olabilmesidir. Rüzgâr potansiyeli yüksek olan ülkelerde rüzgâr santrali kurularak kendi enerjisini üretmesi, güneş enerjisi potansiyeli yüksek olan ülkelerin güneş enerjisi santralleri kurarak enerji ihtiyacını karşılaması ve deprem riski yüksek olan bölgelerde jeotermal enerji potansiyelinin yüksek olması ve bunun elektrik enerjisine dönüştürülerek kullanılması olarak sıralanabilmektedir. Yenilenebilir enerji kaynaklarının çeşitli yöntemler ile elektrik enerjisine dönüştürülmesi ülkelerin enerji güvenliğini de sağlamasına katkıda bulunması beklenmektedir.

Fosil yakıtları bakımından fakir olan ülkemiz yenilenebilir enerji kaynakları açısından zengin ülkeler arasındadır. Bu bakımdan yenilenebilir enerji kaynakları ülkemiz için çok büyük önem arz etmektedir [7]. Bulunduğu coğrafya itibari ile güneş enerjisini bolca alması, yükseltisinin fazla olmasına bağlı olarak yeteri kadar rüzgâr alması, genç bir ülke olması itibari ile de jeotermal enerjinin fazla olması gibi birçok etkenden dolayı ülkemiz yenilenebilir enerji kaynakları açısından avantajlı konumdadır. Dünyadaki Jeotermal enerjinin \%8'inin ülkemizde olması bunun bir göstergesidir [5].

Fosil tabanlı enerji kaynaklarının çevreyi kirletmesi ve yaşanan enerji krizleri de ülkemizde yenilenebilir enerji kaynaklarına olan ilginin artmasında etkili olmaktadır. Bu nedenle ülkemizde yenilenebilir enerji kaynaklarının potansiyelinin araştırılması ve düzenli bir şekilde yürütülmesi için 2 Kasım 2011'de 662 say1lı Kanun Hükmünde Kararname ile Yenilenebilir Enerji Genel Müdürlü̆g̈ü (YGEM) kurulmuştur [8]. Ülkemizde en çok kullanılan yenilenebilir enerji kaynakları sırasıyla; Hidrolik, Rüzgâr, Jeotermal, Biyogaz ve Güneş enerjisidir [9].

\section{3. Ülkemizdeki Rüzgâr Enerjisi Potansiyeli}

Rüzgâr enerjisi; yeryüzüne gelen güneş 1sınlarının yeryüzünü farklı şekillerde 1sıtması sonucunda alçak ve yükssek hava akımları oluşmasına neden olmaktadır. Oluşan bu hava akımları da rüzgâr enerjisini oluşturur. [10]. Ülkemiz yükseltinin fazla olmasına bağlı olarak yüksek oranda rüzgâr enerjisi potansiyeline sahip ülkeler arasındadır. Ülkemizde coğrafi bölgeler bazında yıllık ortalama rüzgâr hızları ve rüzgâr yoğunlukları Şekil 1'de verilmektedir.

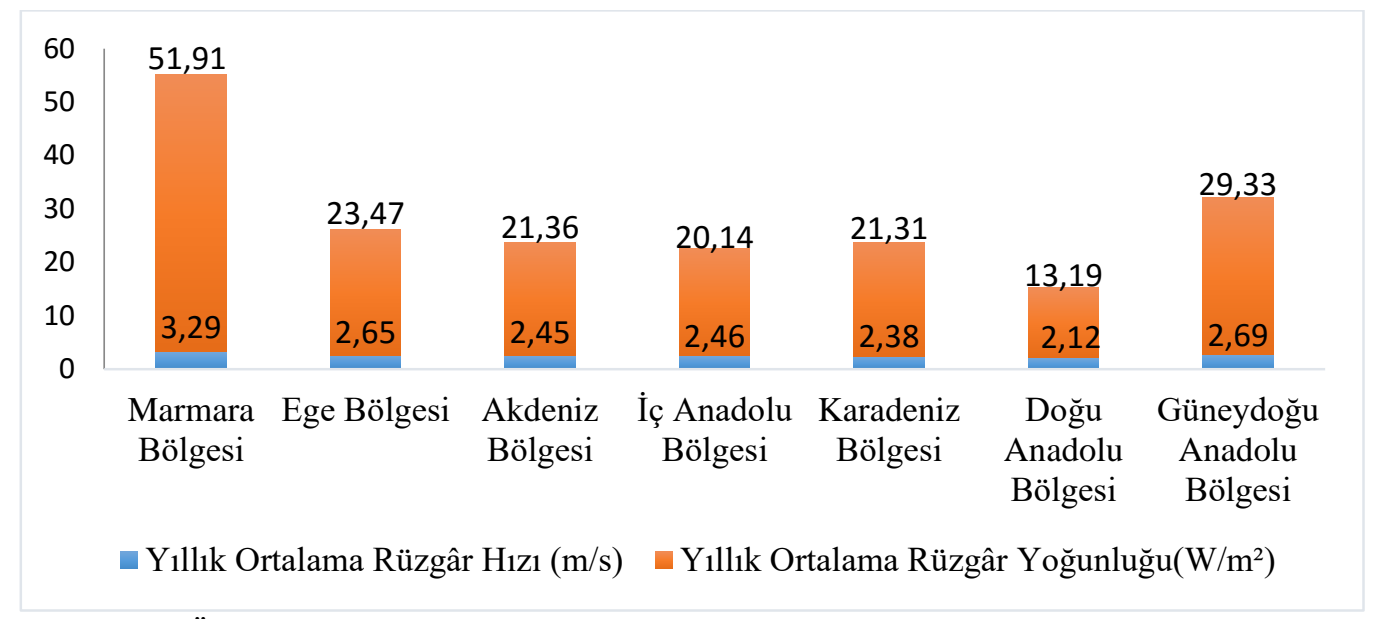

Şekil 1. Ülkemizde coğrafi bölgelerin yıllık ortalama rüzgâr hızları ve yoğunlukları [11]. 
Şekil 1'de görüldüğü gibi ülkemizin ortalama rüzgâr enerjisi potansiyeli oldukça yüksektir. Ayrıca rüzgâr enerjisi potansiyeli bakımından Marmara Bölgesi en çok rüzgâr potansiyeline sahip bölgemizdir. Ülkemizde rüzgâr enerjisi ile ilgili ilk santral İzmir Çeşme-Alaçatı'da 1998 yılında 1.5 MW kurulu gücüne sahip $3 \times 500 \mathrm{~kW}$ Enercon türbinleri ile kurulmuştur. Bu tarihten sonra da rüzgâr enerjisi santralleri kurulumu hızla artmış ve ülkemizde şu anda kullanılan yenilenebilir enerji kaynakları arasında ikinci en çok kullanılan yenilenebilir enerji kaynağı konumundadır [9].

$\mathrm{Bu}$ bölümde elde edilen sonuçlara yer verilmeli, sonuçlar gerekirse şekil ve tablolarla desteklenmelidir. Elde edilen bulgular gerekiyorsa ilgili literatür ile karşılaştırılabilir. Bulgular yeterince açık ve özlü olmalıdır. Tartışma kesiminde, çalışmanın dikkate çekici sonuçları ön plana çıkarılmalı ve aşırı atıf ile literatür tartışmasından sakınılmalıdır.

\section{Rüzgâr Enerjisinden Elektrik Enerjisi Elde Etme}

Dünyada rüzgâr enerjisinden elektrik enerjisi üretimi ilk defa Danimarka'da 1891 yılında Paul la Cour tarafindan yapılan yel değirmeni ile gerçekleşmiştir. Bu çalışmadan sonra rüzgâr enerjisi ile çalışmalar Avrupa'ya yayılmış ve Risoe National Laboratuarı yardımı ile Avrupa Rüzgâr Atlası hazırlatılmıştır. $\mathrm{Bu}$ tarihten sonra kurulan rüzgâr türbinleri yapıları değiş̧irilerek daha çok elektrik enerjisi üretilmesi amaçlanmıştır. Tarih içerisinde kurulan rüzgâr türbinlerini mekanik olarak incelenirse türbinlerin dönme eksenine göre dikey eksenli ve yatay eksenli olarak ayırılmaktadır [12]. Bu şekilde yapılmasındaki temel sebep rüzgâr enerjisinden daha fazla yararlanılması olayıdır. Şekil 2'de çeşitli rüzgâr türbinleri gösterilmektedir.

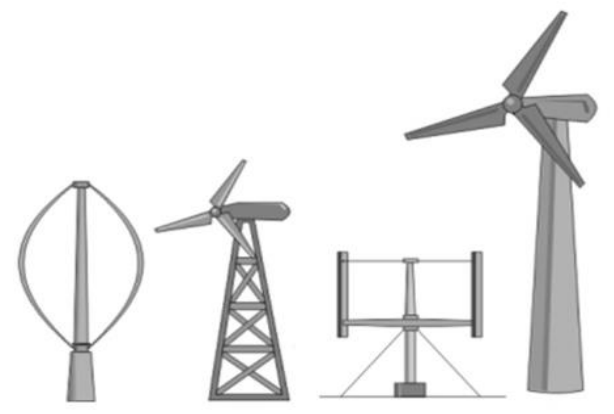

Şekil 2. Rüzgâr Türbinleri

Rüzgâr türbinlerinin çalışma prensibine baktığımızda temelde kinetik enerjiyi potansiyel enerjiye çeviren sistemlerdir. Gelen rüzgâr hızına bağlı olarak farklı hızlara ulaşan türbinler farklı güçlerde elektrik enerjisi üretirler. Şekil 3’te rüzgâr türbininin iç yapısı gösterilmektedir.

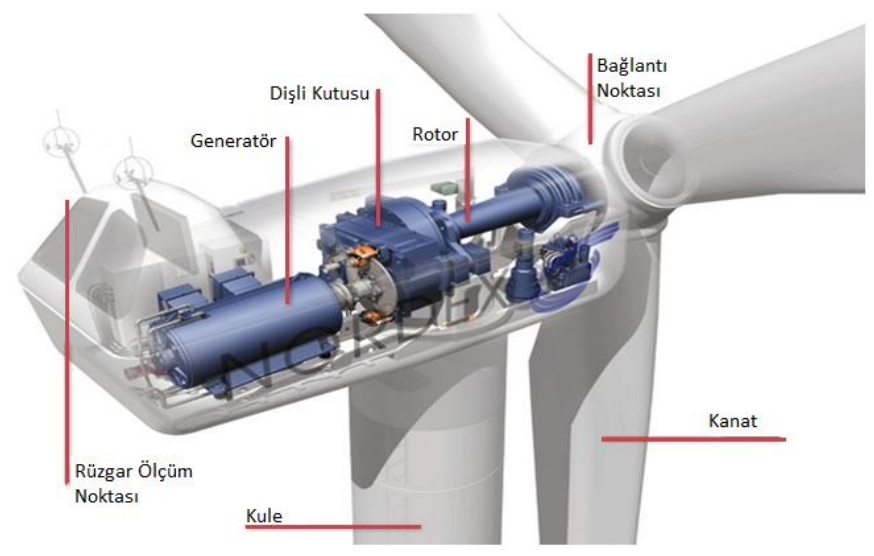

Şekil 3. Rüzgâr türbini içyapısı

Rüzgâr santralleri kurulmadan önce o bölgenin rüzgâr enerjisi potansiyelinin belirlenmesi gerekmektedir. Rüzgâr enerjisi santrallerinin ilk kurulum maliyetlerinin yüksek olmasından dolayı yapılan yanlış bir hesaplama büyük oranlarda parasal kayıplara neden olabilmektedir. Santral 
kurulmadan önce yapılan bu çalışmaların amacı yapılması planlanan santralin bölgede esen rüzgâra göre seçilmesini sağlamaktadır. Böylece oluşabilecek parasal kayıpların önüne geçilmesi düşünülmektedir. Şekil 4'te bir rüzgâr türbinine giren rüzgârın türbin üzerinde oluşturduğu etki gösterilmektedir. Rotor düzlemine gelen rüzgâr enerjisi hesabı ise aşağıdaki denklemler ile bulunmaktadır.

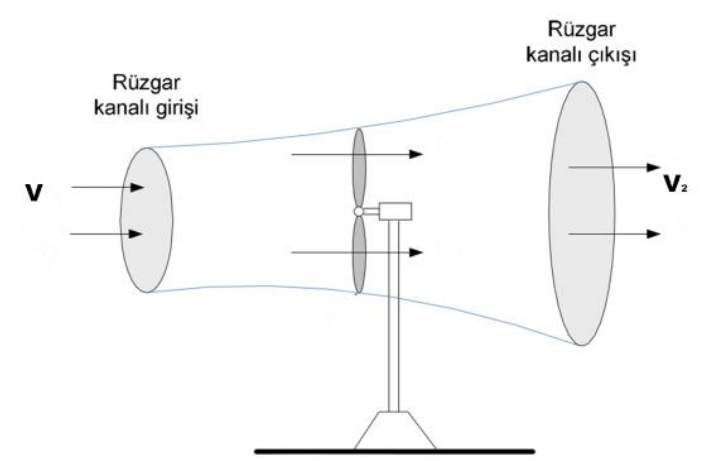

Şekil 4. Rüzgâr türbinine giren rüzgârın etkisi

$v_{1}=\frac{1}{2} \cdot\left(v+v_{2}\right)$

Burada;

$v_{1}$ : rotor düzlemindeki ortalama rüzgâr hızını,

$v$ : rotor düzleminin önündeki rüzgâr hızını,

$v_{2}$ : rotor düzleminin arkasındaki rüzgâr hızını göstermektedir.

Bir bölgedeki rüzgâr hızını belirlemek için en çok kullanılan yöntemler Weibull ve Rayleigh dağılımı yöntemleridir [13].

İki değişkenli Weibull dağılımı olasılık yoğunluk fonksiyonu $f(x)$ aşağıdaki gibidir.

$f(v)=\frac{k}{c}\left(\frac{v}{c}\right)^{k-1} \exp \left[-\left(\frac{v}{c}\right)^{k}\right]$

Burada;

$v$ : rüzgâr hızını $(\mathrm{m} / \mathrm{s})$,

$k$ : boyutsuz şekil parametresini,

$c:$ ölçek parametresini $(\mathrm{m} / \mathrm{s})$ göstermektedir.

Yukarıda verilen denklemdeki değerleri açıklamak gerekirse k (boyutsuz şekil parametresini) rüzgârın sıklığını gösteren bir parametredir. Belli bir coğrafi alanda esen rüzgâr çok fazla değişkenlik göstermiyorsa, yani yaklaşık olarak sabit bir hızda esiyorsa $\mathrm{k}$ boyutsuz sekil parametresi büyük kabul edilmektedir. C ölçek parametresi, birikimli (kümülatif) ortalama hıza bağlı olarak değişir. Ortalama hız değerleri yüksek ise c parametresi de yüksektir [14].

Rayleigh dağılım fonksiyonu ise;

$f_{r}(v)=\frac{\pi}{2} \cdot \frac{v}{\bar{v}^{2}} \exp \left[-\left(\frac{\pi}{4}\right) \cdot\left(\frac{v}{\bar{v}}\right)^{2}\right]$

Şeklinde ifade edilmektedir.

Burada;

$\bar{v}$ : ortalama rüzgâr hızını ifade etmektedir [15]. 


\section{Kilis İli Rüzgâr Potansiyelinin Belirlenmesi}

Ülkemizde rüzgâr enerjisi ile ilgili çalışmaları Yenilenebilir Enerji Genel Müdürlüğü'nce yürütülmektedir. Genel Müdürlük 2006 yılında ülkemizin rüzgâr enerjisi potansiyelini belirlemek için "Türkiye Rüzgâr Enerjisi Potansiyel Atlası" (REPA) hazırlanmıştır. Bu atlasın içerisinde küresel atmosferik sirkülasyon modeli, orta ölçekli sayısal hava analiz modeli ve mikro ölçekli rüzgâr akış modeli kullanılarak üretilen rüzgâr kaynak bilgilerini yer almaktadır. Ülkemizde 50 metre yükseklikteki rüzgâr haritası şekil 5'te verilmiştir.

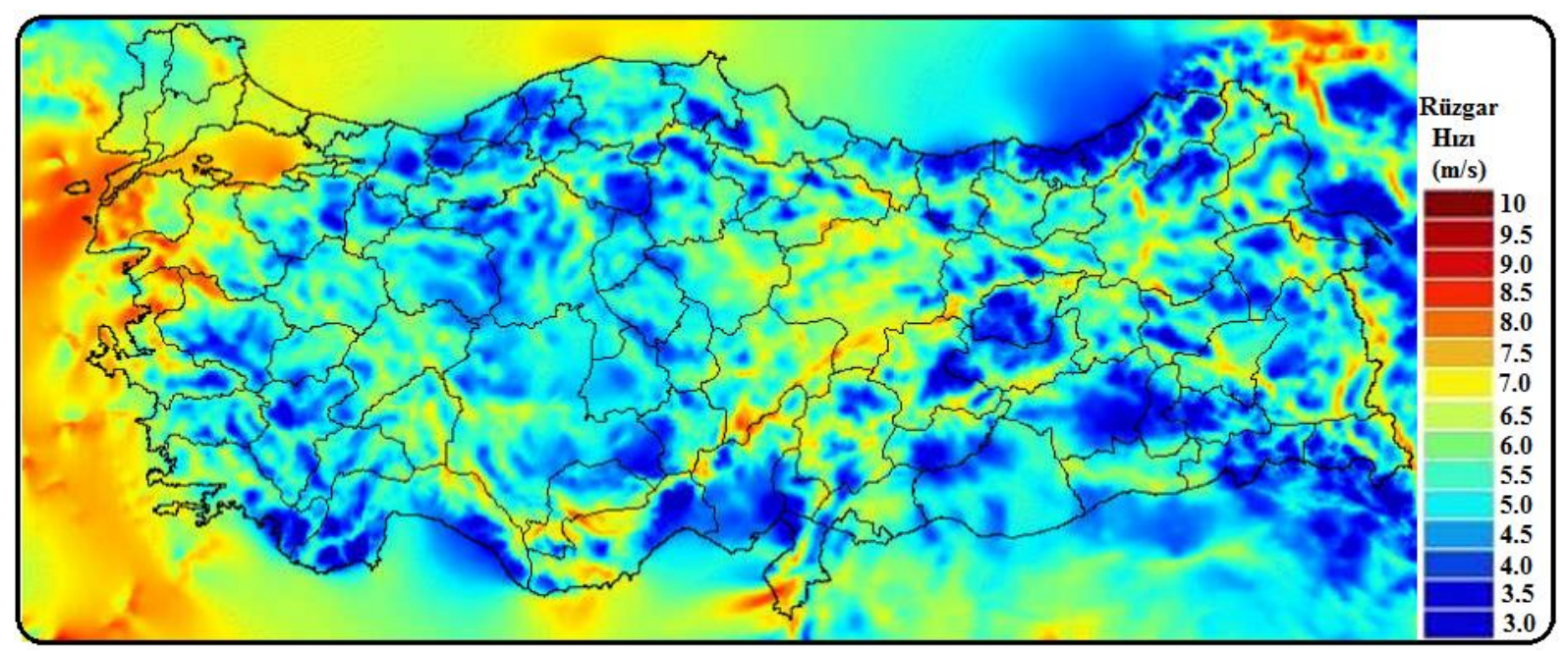

Şekil 5. Ülkemizde 50 metre yükseklikteki rüzgâr hızı [8]

Haritadan da görüldüğü gibi Kilis İlinin ortalama rüzgâr hızı birçok bölgeye oldukça iyi bir durumdadır. Yapılan ölçümler neticesinde Kilis ilinin yıllık ortalama rüzgâr hızı 2,8 m/s'dir. Fakat rüzgâr santrallerinin verimli bir şekilde çalışabilmesi için o bölgenin rüzgâr hızının $7 \mathrm{~m} / \mathrm{s}$ olması gerekmektedir [8]. Bu bakımdan il olarak Kilis'i incelersek kurulacak olan santral bölgeleri Şekil 6'daki yerlere kurulduğunda daha ekonomik ve getirisi daha yüksek olur. Harita 50 m yükseklikteki rüzgâr hızlarını göstermektedir.

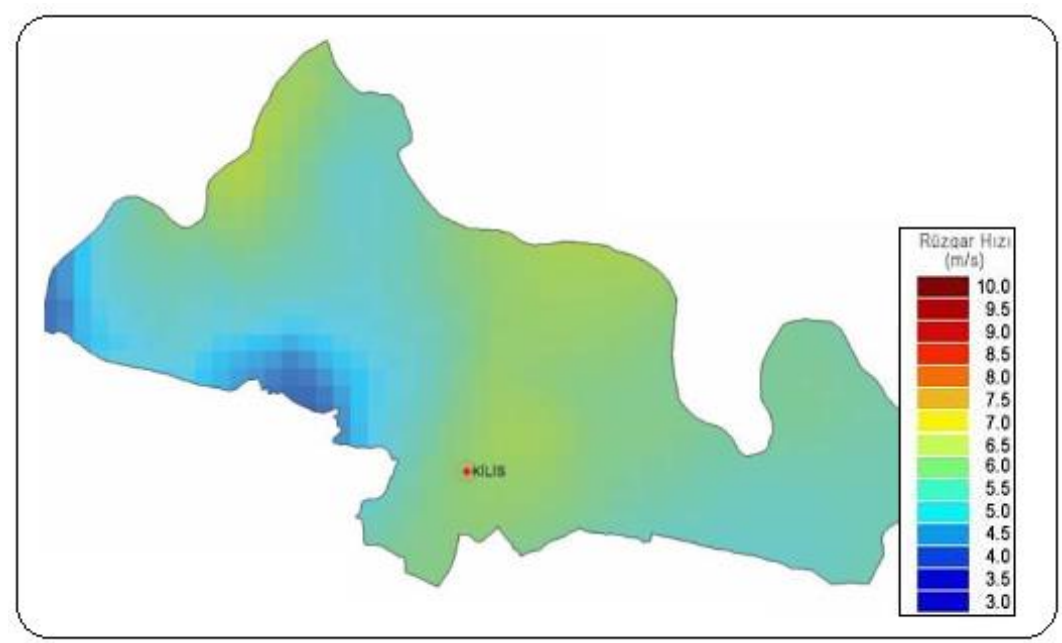

Şekil 6. Kilis İli 50 metre yükseklikteki rüzgâr hızları [8]

Yapılan bu çalışmada tahmini yöntemlere göre rüzgâr hızı ölçümü yapıldığından öncelikli olarak daha önce gerçek cihazlar ile ölçülmüş olan belirli bir yükseklikteki rüzgâr hızlarının bilinmesi gerekmektedir. Bu veriler 1şığında Kilis ili Meteoroloji İşleri Müdürlüğ̈̈'nden alınan 10 metre yükseklikteki rüzgâr hızları dikkate alınarak işlem yapılmaktadır. Tahmini yöntemlere göre rüzgâr hızı hesaplaması yapılırken denklem 4'de verilen değerler kullanılmaktadır. 
$v(h)=\frac{u^{*}}{k} \cdot \ln \frac{h}{z_{0}}$

İfadesi kullanılır.

Burada;

$v=\mathrm{h}$ yüksekliğindeki rüzgâr hızı,

$h=$ Rüzgâr hızının yerden yüksekliği,

$u^{*}=$ Rüzgâr hızı yükseklik faktörü,

$k=$ Von Karman sabiti (0.4),

$Z_{0}=$ Yer yüzeyinden kaynaklanan pürüzlülük faktörünü göstermektedir.

Denklem 4'e göre işlem yapılabilmesi için sadece rüzgâr hızının yeterli olmadığı aynı zamanda diğer ifadeler ile birlikte rüzgârın hızına etki eden pürüzlülük faktörünün de bilinmesi gerekmektedir. Pürüzlülük faktörü santralin çalışmasına olumsuz yönde etki eden dağ, tepe gibi etmenlerin yanında rüzgârın hızını kesen binalar, yerleşim birimleri olarak ifade edilebilir. Bu bakımdan yapılan hesaplamalar neticesinde rüzgârın hızına olumsuz yönde etki eden pürüzlülük faktörü sınıflandırılarak, etki ettiği değer bir katsayı değerine dönüştürülmektedir. Tablo 1'de sınıflandırılan pürüzlülük faktörü ve değerleri verilmektedir [16].

Tablo 1. Pürüzlülük sınıfı ve değerleri [16]

\begin{tabular}{|c|c|c|c|}
\hline $\begin{array}{l}\text { Pürüzlülük } \\
\text { Sınıfı }\end{array}$ & $\begin{array}{l}\text { Pürüzlülük } \\
\text { Uzunluğu (m) }\end{array}$ & $\begin{array}{c}\text { Enerji } \\
\text { Göstergesi }\end{array}$ & Yüzey Şekil \\
\hline 0 & 0,0002 & 100 & Su yüzeyleri \\
\hline 0,5 & 0,0024 & 73 & $\begin{array}{l}\text { Açık araziler (Beton, uçaklar için iniş alanı, } \\
\text { otoban, biçilmiş çim vb.) }\end{array}$ \\
\hline 1 & 0,03 & 52 & $\begin{array}{l}\text { Uzak aralıklı yapılara sahip çitsiz ve engelsiz } \\
\text { açık tarımsal araziler. (Çok hafif engebeli) }\end{array}$ \\
\hline 1,5 & 0,055 & 45 & $\begin{array}{l}\text { Birkaç binalı ve } 1250 \mathrm{~m} \text { mesafeli } 8 \mathrm{~m} \\
\text { yüksekliğinde çitlere sahip tarımsal araziler. }\end{array}$ \\
\hline 2 & 0,1 & 39 & $\begin{array}{l}\text { Birkaç binalı ve } 1250 \mathrm{~m} \text { mesafeli } 8 \mathrm{~m} \\
\text { yüksekliğinde çitlere sahip tarımsal araziler. }\end{array}$ \\
\hline 2,5 & 0,2 & 31 & $\begin{array}{l}\text { Birkaç binalı ve } 500 \mathrm{~m} \text { mesafeli } 8 \mathrm{~m} \\
\text { yüksekliğinde çitlere sahip tarımsal araziler. }\end{array}$ \\
\hline 3 & 0,4 & 24 & $\begin{array}{l}\text { Pek çok bina, çalı ve bitkiye sahip, yada } 250 \mathrm{~m} \\
\text { mesafeli } 8 \mathrm{~m} \text { yüksekliğinde çitlere sahip tarımsal } \\
\text { araziler. }\end{array}$ \\
\hline 3,5 & 0,8 & 18 & $\begin{array}{l}\text { Köyler, küçük şehirler, çok yada yüksek çitli } \\
\text { tarımsal araziler, ormanlar, çok yoğun ve } \\
\text { pürüzlü bölgeler. }\end{array}$ \\
\hline 4 & 1,6 & 13 & Yüksek yapılara sahip büyük şehirler \\
\hline 0 & 0,0002 & 100 & $\begin{array}{l}\text { Yüksek binalara ve gökdelenlere sahip } \\
\text { büyük şehirler }\end{array}$ \\
\hline
\end{tabular}

Yaptığımız bu çalı̧̧ma Kilis İli olduğundan dolayı köylerin, tarımsal arazilerin çok olduğunu göz önünde bulundurarak yüzey pürüzlülük faktörü 0,4 olarak kabul edilmektedir. Kilis İli Meteoroloji İşleri Genel Müdürlüğü'nden almış olduğumuz verilerde 10 metre yükseklikteki rüzgâr hızı mavi renkli çizgiler Şekil 7'de gösterilmektedir. Denklem 4'de 10 metre yükseklikteki rüzgâr hızının ve diğer değerlerin birlikte girilmesi sonucunda herhangi bir günde tahmini ölçümü yapılan 30, 40, 60 ve 80 metre yükseklikteki rüzgâr hızları Şekil 7'de verilmektedir. 


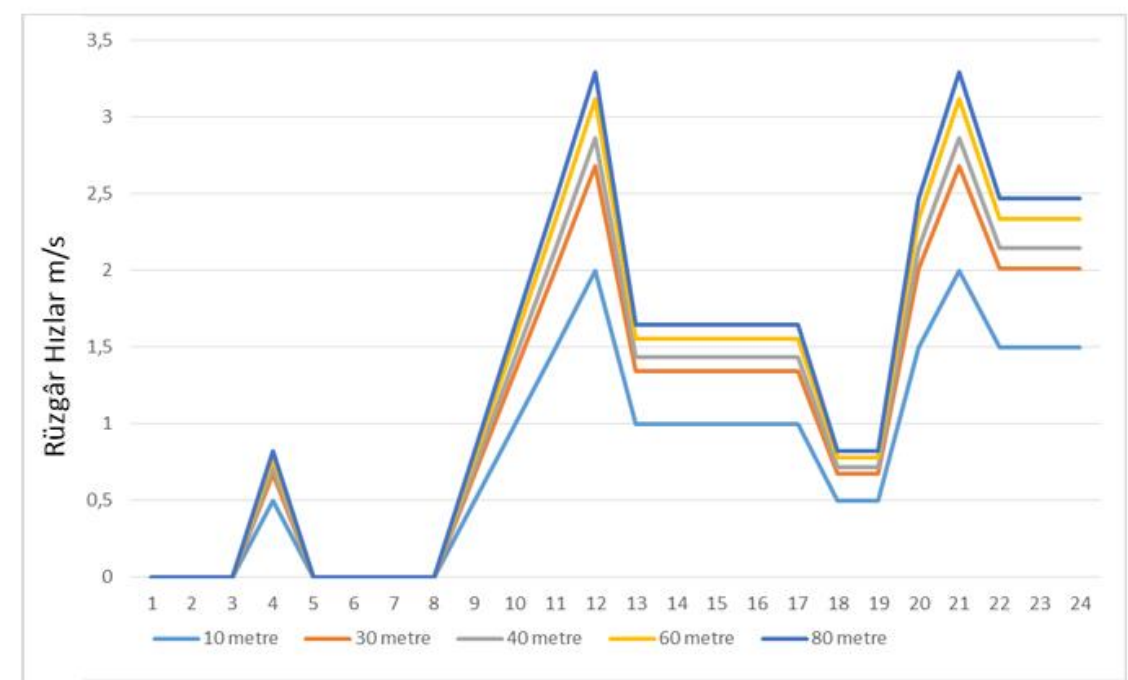

Şekil 7. Farklı yüksekliklerdeki herhangi bir günde tahmini rüzgâr hızı

Bir gün için yapılan bu hesaplama dikkate alınarak Kilis íli Meteoroloji İşlerinden alınan 10 metre yükseklikteki yıllık rüzgâr hızları ile birlikte ay bazında ve yıl bazında 30, 40, 60 ve 80 metre yükseklikteki tahmini rüzgâr hızları çıkarılmaktadır. Şekil 8 'de 12 aya dağılmış olan aylık bazda rüzgâr hızları verilmektedir. Bu şekil yardımı ile rüzgâr potansiyelinin en fazla olduğu aylar kolaylıkla görülebilmektedir.

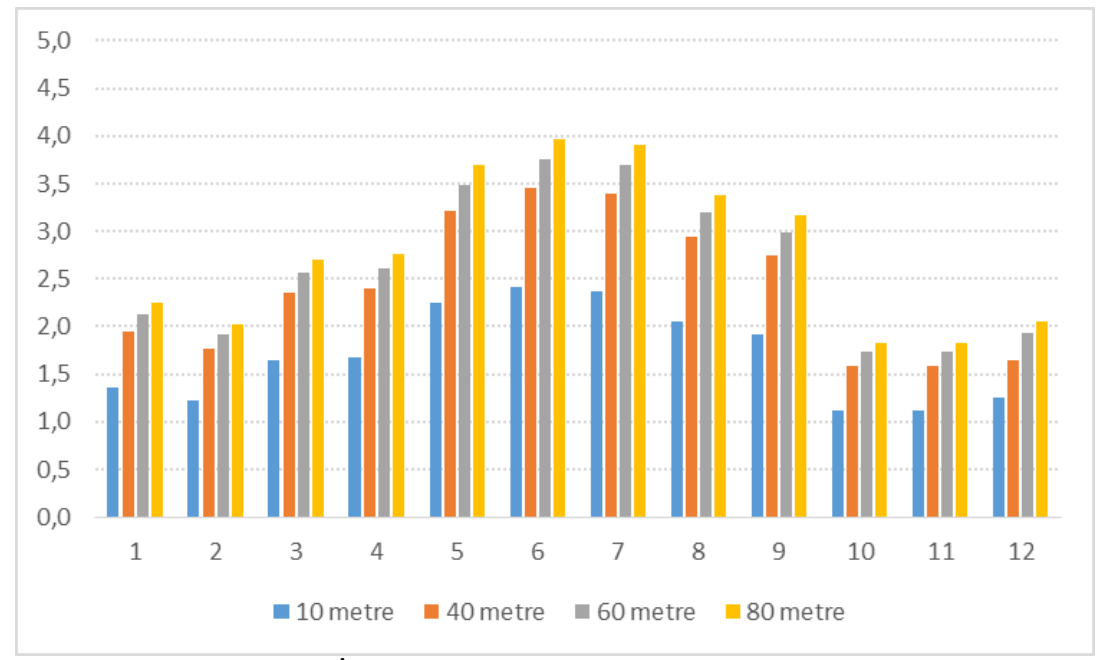

Şekil 8. Kilis İli farklı yüksekliklerdeki aylık rüzgâr hızları

Rüzgâr potansiyeli bakımından yüksek olan ülkemizde rüzgâr santrallerinin verimli çalışabilecekleri yükseklikler 50 metre ve üzerinde olmaktadır. Yapılan çalışmalar neticesinde 50 metre yükseklikte rüzgâr hızı $7,5 \mathrm{~m} / \mathrm{s}$ olmakta olup bu he kilometre için $5 \mathrm{MW}$ gücüne sahip bir rüzgâr santrali kurulabileceğini ifade etmektedir [18]. Kilis ili için yapılan çalışmada 50 metre yükseklikteki rüzgâr hızının 5,5 ile 6,5 arasında olduğu belirtilmektedir [8]. Bu durumda 50 metre ve altı için bu bölgeye rüzgâr santralinin kurulumunun uygun olmadığını göstermektedir. Bu veriler dikkate alınaraktan çalışmada 60 metre ve 80 metre yükseklikteki tahmini rüzgâr hızları çıkarılmaktadır. Şekil 9'da yıllık bazda 10, 30, 40, 60 ve 80 metredeki tahmini rüzgâr hızları verilerek santralin 50 metre altında kurulması durumunda verimsiz olabileceği açıkça görülmektedir. 


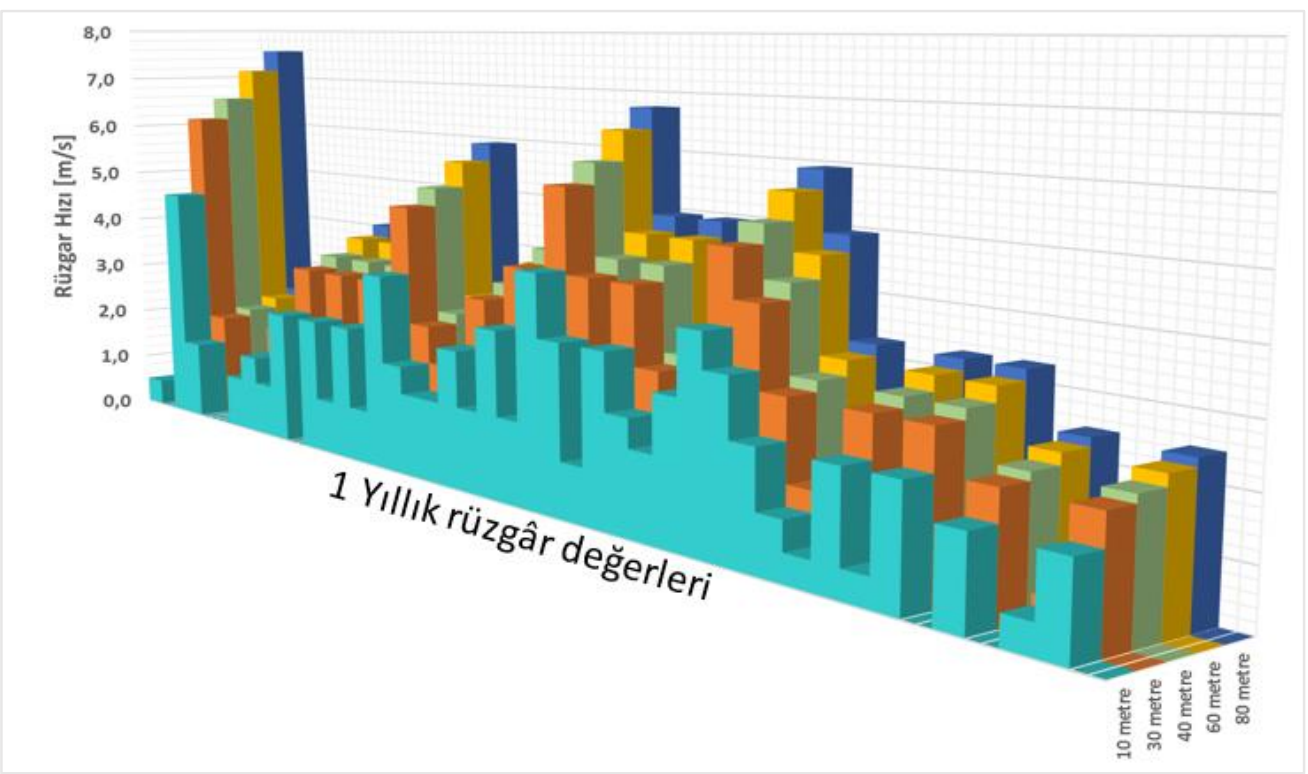

Şekil 9. Yı1lık Rüzgâr Hızları

Ülkemizde Enerji ve Tabii Kaynaklar Bakanlığının yaptı̆̆ çalışmalar sonucunda belirlediği rüzgâr hızlarına göre $6,5 \mathrm{~m} / \mathrm{s}$ esen rüzgârın orta düzeyde olduğu, $7,5 \mathrm{~m} / \mathrm{s}$ hızla esen rüzgârın iyi düzeyde olduğu ve $8,5 \mathrm{~m} / \mathrm{s}$ hızla esen rüzgârın ise çok iyi bir rüzgâr potansiyelin olduğu ifade edilmektedir [18].

\section{Kaynaklar}

1. Bacanlı Ü.G. 2010. Türkiye'de Enerji Kaynakları ve Hidroelektrik Enerjinin Önemi. http://www.dektmk.org.tr/pdf/enerji_kongresi_10/UlkerGunerBacanli.pdf. (Erişim Tarihi: 10.12.2016).

2. Rüstemli S., Cengiz M.S., Dinçer F. 2011. Van İli Elektrik Enerjisinin Dünü, Bugünü ve Yarını, Kaynak Elektrik Enerji, Elektrik, Aydınlatma, Elektronik ve Otomasyon Mühendisliği Dergisi, 16 (1): $22-33$.

3. Rüstemov S.A., Demirtas M. 2004. Rüzgâr Enerjisinin Bugünü ve Yarını, UTES 2004 V.Ulusal Temiz Enerji Sempozyumu, İstanbul.

4. Rüstemli S., Oral F., Akdağ M. 2013. Bitlis İli Elektrik Enerjisi Üretiminde Rüzgâr Enerjisinin Önemi, 9. Ulusal Temiz Enerji Sempozyumu, UTES, Konya.

5. Gençoğlu M.T. 2002. Yenilenebilir Enerji Kaynaklarının Türkiye Açısından Önemi. http://www.solar-academy.com/menuis/Yenilenebilir-Enerji-Kaynaklarinin-Turkiye-AcisindanOnemi.005039.pdf. (Erişim Tarihi: 12.12.2016).

6. Çalıskan M. 2007. Orta Karadeniz Bölgesi Rüzgâr Enerjisi Potansiyeli. http://www.emo.org.tr/ekler/09260384253eef3_ek.pdf. (Erişim Tarihi: 12.12.2016).

7. Rüstemli S., Polat Dautov Ç., Akdağ M. 2016. Bitlis İli Elektrik Enerjisinin Dünü, Bugünü ve Yarın, Bitlis Eren Üniversitesi Fen Bilimleri Dergisi, 5 (2): 172-182.

8. Süzek F. 2007. Türkiye Rüzgâr Enerjisi Potansiyelinin Belirlenmesi. İstanbul Teknik Üniversitesi, Fen Bilimleri Enstitüsü, Makine Mühendisliği Anabilim Dalı Yüksek Lisans Tezi, 127s, İstanbul.

9. Enerji Atlası 2016. Türkiye Elektrik Üretimi. http://www.enerjiatlasi.com/elektrik-uretimi/ (Erişim Tarihi: 17.12.2016).

10. İlkılıç C. 2009. Türkiye'de Rüzgâr Enerjisi Potansiyeli ve Kullanımı, Mühendislik ve Makine, 50 (593): 26-32. 
11. Çukurova Kalkınma Ajansı 2012. Yenilenebilir Enerji Raporu 2012. http://www.cka.org.tr/dosyalar/2012ckafaaliyetraporu05042013.pdf. (ErişimTarihi:15.12.2016).

12. Çolak İ., Demirtaş M. 2008. Rüzgâr Enerjisinden Elektrik Üretiminin Türkiye'deki Gelişimi, Türk Bilim Dergisi, 1 (2): 55-62.

13. Almalı M.N., Rüstemli S., Gürcan K. 2013. Ortalama Rüzgâr Hızı ve Güç Yoğunluğunun Tahmin Edilmesinde Kullanılan Farklı Yöntemler, Iğdır Üniversitesi Fen Bilimleri Dergisi, 3 (1): 73-78.

14. Şekerci E., Monie E., Albasan C. 2013, Rüzgâr Türbini Tahmini Y1llık Enerji Üretim Hesaplama Yöntemleri ve Araziye Uygun Rüzgâr Türbini Seçimi. http://www.emo.org.tr/ekler/1ae9a071e07049a_ek.pdf. (Erişim Tarihi: 20.12.2016).

15. Taşkın A. 2013. Rüzgâr Enerjisinden Elektrik Üretiminin Yaşam Döngü Analizi. Erciyes Üniversitesi, Fen Bilimleri Enstitüsü, Makine Mühendisliği Anabilim Dalı Yüksek Lisans Tezi, 93s, Kayseri.

16. Vardar A. 2013. Rüzgâr Türbin Tipleri ve Rüzgârdan Elde Edilecek Enerjinin Belirlenmesi. http://slideplayer.biz.tr/slide/2335624/. (Erişim Tarihi: 20.12.2016).

17. Meteoroloji İşleri Genel Müdürlüğü. 2016. Kilis İli Meteoroloji İşleri Genel Müdürlüğü. https://www.mgm.gov.tr/. (Erişim Tarihi: 18.12.2016).

18. Enerji ve Tabi Kaynaklar Bakanlığı 2016. Rüzgâr Enerjisi. http://www.enerji.gov.tr/trTR/Sayfalar/Ruzgar. (Erişim Tarihi: 21.12.2016). 